\title{
Memórias de um Cabra Marcado pelo Cinema: representações de um Brasil rural
}

Eliska Altmann O desenvolvimento da arte da memória - e sua transição das tradições orais, com PPGAS/IFCS suas técnicas mnemônicas, para a produção moderna nas sociedades complexas - revela que sua função se estabelece enquanto "um dos meios fundamentais de abordar os problemas do tempo e da história, relativamente aos quais a memória está ora em retraimento, ora em transbordamento" (Le Goff 2003:422). Dentre os desdobramentos contemporâneos dos suportes mnemônicos é possível ressaltar os estatutos imagéticos que, através das tecnologias visuais, operam estilos cognitivos de forma a organizar as sociedades. Tais estilos têm enfatizado um caráter cada vez mais híbrido, com linguagens fotográfica, fílmica, televisiva, informática, entre outras. Por meio de sua capacidade de reproduzir ficcionalmente as diversas realidades, estas expressões das múltiplas memórias são elaboradas de forma a serem permanentemente re-significadas, reordenando, nesse sentido, a maneira com que o homem percebe a realidade.

Tais representações do real ou "ficções históricas" "reconstroem momentos da história oficial, geram uma espécie de curto-circuito entre a função narrativa - em sua dupla expressão ficcional e histórica - e a experiência do tempo, criando, assim, um impasse sobre a memória" (Ricoeur 1998:17). Esse argumento a respeito da relação entre imagem e real faz com que questionemos os fundamentos da própria realidade. Tal discussão já estava na base da teoria sociológica, sendo trabalhada por seus fundadores, Durkheim, Weber e Marx, que propunham realidades diversas apreensíveis por metodologias particulares. Se para esses três pensadores não existe de imediato o real, para o que é que nós olhamos diretamente? Para Durkheim, as pré-noções, os pré-conceitos, para Weber, o caos, e para Marx, a ideologia e os 
espécie de imaginário social; o que significaria que sua imagem seria muito mais um ponto de referência na cultura do que na própria "realidade" (Menezes 2003:89-90).

Desta forma, sob o prisma da construção do real pelo cinema, veremos como Cabra Marcado para Morrer compõe e ordena sua narrativa com base em um contexto histórico agrário em que movimentos organizados lutaram por uma legitimação. $O$ artigo se divide em cinco tópicos: 1) o campo cinematográfico da década de 60, os interesses e as trajetórias de seus respectivos agentes, e a obra de Eduardo Coutinho nele inserida; 2) a construção do filme, cujo roteiro ficcional dá lugar à improvisações "reais" dos atores-camponeses e sua comparação com outra obra de mesma temática e contexto; 3) a opção estética do diretor enquanto emblema para uma discussão teórica; 4) o espaço social em que Cabra está inserido e a formação das Ligas Camponesas; 5) a concepção do contexto agrário enquanto memória e o filme de Eduardo Coutinho, que efetua uma ponte com a história. Nesse sentido, o norte essencial do artigo é tentar entender como as memórias de determinado período se cristalizam em imagens criadas através de um real construído.

\section{O CABRA E A BUSCA DA "BRASILIDADE"}

Das imagens cinematográficas tratadas no presente artigo enfatizamos as dos anos 60 por terem sido de grande importância político-cultural, na medida em que trataram importantes aspectos nacionais, contribuindo significativamente no processo de formação da identidade cultural nacional. Nesse momento, o movimento que se destaca no campo cinematográfico é o Cinema Novo. Sua importância não está apenas no interesse em produzir filmes cooperativamente, como um claro exemplo da estrutura de sociabilidade proporcionada pelos movimentos artísticos em geral, mas em representar "não apenas um novo começo para o cinema brasileiro, como uma nova definição do papel social do cinema, não mais reconhecido como uma mera forma de entretenimento, mas como um modo de intervenção artística e cultural na conjuntura histórico-social de um país" (Johnson 1995:363). Como sugere Ismail Xavier, no Cinema Novo "atualidade era a realidade brasileira, vida era o engajamento ideológico, criação era buscar uma linguagem adequada às condições precárias e capaz de exprimir uma visão desalienadora, crítica, da experiência social" (Xavier 1985:14).

Na filmografia brasileira da década de 1960 verifica-se a presença de questões relativas à contribuição dos filmes para o processo de formação da identidade nacional brasileira e análises da produção sócio-cultural a partir de seus vínculos metonímicos com a nação. Pode-se dizer que diretores como Glauber Rocha, Joaquim Pedro de Andrade, Nelson Pereira dos Santos, entre outros, são tratados como uma categoria social de intelectuais e 
artistas empenhados em projetos de produção cultural que visavam a definição de "identidade" para a nação e a formação de uma consciência sócio-política para setores populares da sociedade brasileira. Com o objetivo de criar interlocuções entre o artista consciente e engajado e o povo, muitos dos cinemanovistas se empenharam na união com artistas, estudantes e intelectuais que visavam exercer a cultura como forma de instrumento revolucionário - como os membros dos Centros Populares de Cultura ${ }^{1}$. Cartas, críticas e manifestos por eles escritos, assim como textos historiográficos, revelam seu empenho em produzir um cinema expressivo que, segundo Glauber Rocha, visava influenciar o "processo dialético da história" (Rocha 1981:25). Filmes como Vidas Secas (1962), de Nelson Pereira dos Santos; Deus e o Diabo na Terra do Sol (1963), de Glauber Rocha; Os Fuzis (1963), de Ruy Guerra; e as primeiras seqüências de Cabra Marcado para Morrer (1964), de Eduardo Coutinho, mostram cineastas empenhados na contribuição de uma arte voltada à conscientização da nação e no processo de formação de sua memória identitária.

Nesse universo de legitimação de um cinema "autoral" e engajado em oposição ao cinema comercial e industrial, Cabra Marcado reflete imagens de um Brasil agrário, de forma a estabelecer um reconhecimento nacional do processo de organização política dos trabalhadores rurais. Articulada a outras cinematografias da década de 60, esta obra demonstra similaridades e rupturas quanto à representação agrária brasileira, atualizando uma espécie de denúncia de um país "subdesenvolvido" e de inserção do cinema nos importantes debates sociais, políticos e culturais.

Ao contrário de outros cinemanovistas contemporâneos, intelectuais e militantes, Eduardo Coutinho, diretor de destaque na história do documentário brasileiro ${ }^{2}$, construiu um caminho sem vinculações partidárias, não participando de movimentos políticos. Deste caminho, a realização de Cabra tornou-se emblemática. Iniciado em 1964, o filme, que se pretendia ficcional, tinha como objetivo a reconstituição da biografia de João Pedro Teixeira, líder assassinado da Liga Camponesa de Sapé, na Paraíba. Das filmagens interrompidas no dia $1^{\circ}$. de abril daquele mesmo ano, com a chegada das tropas do exército, decorrente da repressão desencadeada pelo golpe de Estado, sobraram algumas seqüências e poucas fotos de cena.

Retomando o projeto quase vinte anos depois, em 1981 (o documentário seria finalizado em 1984), Eduardo Coutinho voltou ao local das filmagens - Engenho da Galiléia, município de Vitória de Santo Antão, Pernambuco - , onde entrevistou trabalhadores que haviam desempenhado papéis de suas próprias condições nas seqüências ficcionais iniciais. Neste reencontro, o diretor registra as reações dos atores-camponeses diante das imagens projetadas, assim como seus depoimentos sobre as mudanças ocorridas em suas vidas desde a interrupção das primeiras filmagens. Paralelamente, lançou-se na busca do paradeiro da viúva do líder assassinado da Liga Camponesa, Elizabeth Teixeira, que vivia na clandestinidade há 16 anos, com o codinome de Marta Maria da Costa. 
A partir de sua localização em São Rafael, pequena cidade no interior do Rio Grande do Norte, deu-se início outra investigação, a busca dos 11 filhos do casal Teixeira que, em 64, tiveram seus destinos dispersos. Alguns foram entregues aos cuidados de familiares, outros se mudaram para cidades grandes como o Rio de Janeiro e ainda houve um mandado para o exterior. As investigações, sempre documentadas por uma pequena equipe de filmagem, levam a que filhos e mãe retomem contato.

$\mathrm{Na}$ tentativa de apreender e reconstituir um dos Nordestes rurais inventados pelo cinema nacional, Cabra Marcado para Morrer é menos um marco do cinema documentário no Brasil do que um documento histórico da memória de um movimento camponês, elaborado através de uma trajetória pessoal bastante díspar e de um processo de realização peculiar. Segundo Jean-Claude Bernardet, Cabra resgata os detritos de uma história escapando às ilusões do historicismo, sendo, portanto, apresentado como um "projeto histórico preocupado em lançar uma ponte entre o agora e o antes, para que o antes não fique sem futuro e o agora não fique sem passado" (2003:227). Para o teórico, o documentário representa um "duplo resgate de uma dupla derrota. O primeiro Cabra, o de 64 e de que sobraram apenas vestígios, já era o resgate de um fracasso: o assassinato de um líder das Ligas Camponesas, João Pedro. O Cabra de hoje resgata o filme interrompido - e, dessa forma, também João Pedro - e resgata a viúva do líder e sua família. (...) Esse processo de resgate da história provoca uma construção 'em abismo', em que a obra se encaixa dentro da obra, o filme dentro do filme" (2003:228-29).

É interessante notar que o resgate do próprio Eduardo Coutinho em relação à questão agrária mostra-se também 'em abismo'. A aproximação do Nordeste feita pelo diretor dá-se através de um curioso itinerário, que revela uma distância inicial em relação ao movimento intelectual e político pró-reforma agrária. Ao estabelecer, apenas posteriormente, contato com contemporâneos integrados em atividades de renovação cultural, Coutinho inicia uma busca frustrada por um Brasil rural junto aos índios, chegando à malograda idéia da adaptação para o cinema de poemas de João Cabral de Melo Neto. Segundo ele,

“em 1962, filmei um comício em protesto à morte de uma pessoa que eu não conhecia e que, aliás, era pouco conhecida no Brasil. Em João Pessoa, soube que era um líder camponês, João Pedro Teixeira, assassinado por policiais militares a mando de um grande proprietário de terras nordestino. (...) Em maio de 1962, eu voltei para o Rio de Janeiro e o Carlos Estevão, que era presidente do CPC, me escolheu para dirigir um longa metragem. A idéia inicial era fazer um filme baseado em O Rio, de João Cabral de Melo Neto. Seria o percurso do rio Capibaribe, com os poemas sociais de João Cabral, mas sem o nascimento da criança, sem o fim de Morte e Vida Severina. O João Cabral, que inicialmente havia concordado com o projeto, nos mandou um telegrama nos dizendo que não estava mais de acordo. Nunca perguntei a ele porque fez isso. Mas pode ter sido o receio dele de poder ser acusado de comunista. Ele é um diplomata e talvez não tenha julgado oportuno se envolver com uma produção do CPC da UNE. E aí partimos para outra história" (Galano 1984:37). 
Apesar de não realizado, o projeto de adaptação da obra de João Cabral já revelava uma tendência do diretor à abordagem cinematográfica do Nordeste rural através da criação literária. Nesse momento, Coutinho passa a demonstrar maior interesse pelo interior e pela reforma agrária, voltando à região com o intuito de filmar Cabra Marcado. Tal interesse

\footnotetext{
“devia ser um pouco por causa da mitologia do Julião ${ }^{3}$. Na época li Os Camponeses; enfim, havia um lado romântico e um outro lado cultural do Nordeste. E juntou as duas coisas pra fazer o filme. $O$ argumento foi esse: eu tinha feito a UNE-Volante $^{4}$ e em abril de 62 passei 2 ou 3 meses no Nordeste. Conheci a Elizabeth, pesquisei e encaminhei o troço para filmar como eu conto no filme" ${ }^{5}$.
}

Em viagem com a UNE-Volante à Paraíba, Eduardo Coutinho, que na época não sustentava nenhuma adesão ideológica, decidira encenar a vida do líder que trágica e coincidentemente tivera sido assassinato poucos dias antes. Mesmo sem possuir vínculo com o Partido Comunista, Coutinho travara contato com importantes líderes de movimentos agrários, como Francisco Julião. Integrante do CPC da UNE mais por conta de uma amizade com Leon Hiszman ${ }^{6}$ do que por ideário próprio, o documentarista propõe, depois da decepção de Cinco Vezes Favela ${ }^{7}$, realizar um filme que teria aquela instituição como produtora. Assim, Cabra seria "o" filme do CPC, uma vez que Cinco Vezes Favela não teria resultado de projeto coletivo, nem da iniciativa dos principais "ideólogos" da instituição, Carlos Estevan Martins e Oduvaldo Vianna Filho ${ }^{8}$. Segundo Eduardo Coutinho, no entanto, apesar de o CPC ter sido produtor de seu filme, foi difícil suscitar o interesse de seus responsáveis pelo projeto. Embora se mostre dissociável das práticas daquela instituição, que defendia uma estética programática, espécie de adaptação tardia do realismo socialista soviético por membros intelectualizados do movimento estudantil, as seqüências iniciais de Cabra integram a documentação cinematográfica da UNE-Volante.

\section{IMPROVISAÇÕES SECAS}

Composto com imagens ficcionais de 1964 e depoimentos documentais de 1981, Cabra Marcado para Morrer mostra a reivindicação camponesa ao longo de vinte anos. As seqüências de Cabra filmadas antes do golpe de 64 são compostas por um duplo estético: as imagens de documentação e os "laboratórios" de dramaturgia com atores-camponeses não-profissionais, que acabaram alterando os diálogos e marcações de cena do roteiro original. Segundo Eduardo Coutinho, em meio às imagens ficcionais do primeiro Cabra, improvisações derivaram na criação de novos diálogos. 
Resulta de improvisação, por exemplo, a seqüência em que trabalhadores e um capataz se confrontam a respeito do valor do foro que os primeiros deveriam pagar ao proprietário da terra. Os dois roteiros do Cabra de 64 têm 423 planos, sem divisão por seqüências, contendo apenas indicações de cenas assinaladas pelo local e momento da filmagem, como, por exemplo, "interior-noite-casa João Pedro". O plano 136, do "tem gente lá fora", realizado em $1^{\circ}$. de abril de 64 , dia da interrupção das filmagens, também procedeu de improviso. A cena ocorre ao final de uma reunião em que se discutia a formação de uma primeira associação em Sapé. A frase é dita por dona Elizabeth ao desempenhar seu próprio papel, isto é, de esposa de João Pedro. Através de comparação de ambos os roteiros escritos pelo diretor em 64, é possível observar que a principal diferença está na inclusão da seqüência filmada no pátio dianteiro de uma casa, na qual os atores-camponeses literalmente criam os diálogos. Conforme indica Coutinho,

\begin{abstract}
“o roteiro só melhorou um pouquinho na preparação do filme. A gente fez um laboratório com eles, foi uma coisa maravilhosa. Aquela cena que está lá do feitor, não tem uma palavra do diálogo que não seja exatamente dita por eles. Pegamos um, o que faz o administrador, botamos seis caras em volta do refeitório da casa e ficaram dizendo. A gente gravou e eu selecionei as falas. Foi exatamente isso, às vezes podia mudar a atribuição da fala de um para o outro, mas basicamente até a distribuição foi exata. Se eu tivesse feito com todas as cenas realmente seria melhor, mas eu fiz com duas só" ${ }^{9}$.
\end{abstract}

No início da cena aparece um feitor irritado com a decisão dos camponeses de irem reivindicar o aumento: “vocês não devia ter vindo de cow-boy. Quando é para pagar o foro, só vem um só. Isso é feio pra vocês. Eu vou mudar a situação da moradia de vocês. Tá muito perto um do outro". Os trabalhadores discutem com o feitor até que um tenta agredi-lo. O feitor reage: “Tá revoltado? Não devia. Seus filhos morre, dou enterro. Sua mulher adoece, boto na maternidade. Nada falta pra vocês". O camponês que interpreta o papel de João Pedro intervém dizendo que o caso não é brigar, mas "o problema é que eles não podem pagar o foro". A situação se acalma e o feitor diz: "Vocês sabem que vocês são meus e eu sou de vocês. Quero que vocês fiquem satisfeitos comigo. Eu não quero brigar. A terra é da gente tudo". Da transcrição de anotações manuscritas por Eduardo Coutinho, verificamos que do plano 96 - em que o administrador fala que "João Pedro é o cabeça, é quem pôs essas idéias na cabeça de vocês" - ao plano 111 - em que o camponês Bernardo responde que "ainda vai ter um dia que o senhor vai querer fazer o que está fazendo e não poder" - prevalece a improvisação.

Esta seqüência pode ser considerada uma das mais importantes do filme justamente por ter sido criada exclusivamente pelos camponeses, que transformaram o roteiro ficcional por meio de suas reivindicações "reais" montadas a partir de suas experiências de conflito e negociação. Nela é possível perceber um feitor que não quer 
briga ao dizer que a decisão dependerá do patrão, e a exaltação de apenas um dos trabalhadores, enquanto os outros tentam acalmá-lo e se vão. Nesse sentido, não há heroísmo dos trabalhadores, nem hostilidade explícita do lado de quem está no poder, ou seja, o Estado.

Montada pelo diretor que se assume um não-engajado, ou melhor, um "vacilante" em relação à ideologia e às práticas cepecistas, a seqüência demonstra uma versão bastante verossimilhante ao Nordeste da época. Assim, contraditoriamente ao discurso de Coutinho, o filme de 64 pode ser concebido enquanto uma denúncia, nem um pouco ingênua, das práticas rurais; denúncia bem enquadrada aos moldes do Cinema Novo na superação de maniqueísmos. Desta forma, Cabra Marcado é um filme de ficção com camponeses, transformado em documentário, não menos denunciativo no novo formato.

Em 1962, em depoimento para Alex Viany na revista Senhor, Eduardo Coutinho não parece tão "desenturmado" quanto diz, pois se revela atualizado não só com as questões políticas brasileiras, mas também com as cinematográficas, no âmbito histórico e industrial-comercial. Dando início à entrevista, Viany apresenta o gerente de produção de Cinco Vezes Favela como um dos "espíritos mais lúcidos da geração do Cinema Novo, já farto de qualquer discussão teórica, particularmente as que versam sobre o 'específico fílmico'" (1962:16). Ao opinar a respeito da situação do cinema nacional Coutinho indica que, com a conscientização e com as reformas que viriam "por bem ou por mal" no Brasil, era natural que se esperasse por um cinema genuinamente brasileiro. Esse caráter nacionalista conferia fundamentalmente um novo estilo ao cinema brasileiro que, segundo Coutinho, deveria "ser livre formalmente, pois todos os caminhos - a montagem intelectual, a improvisação, o plano demorado - podem levar ao que interessa: o tratamento crítico de um tema vinculado à realidade brasileira. (...) É importante o simples ato de mostrar o que é a realidade brasileira, sem propostas explícitas: como se alimenta o brasileiro, como trabalha, como sofre, como luta, como fala" (Viany 1962:17). Com isso, é possível verificar que a trajetória do documentarista, por mais díspar que tenha sido em comparação aos outros cinemanovistas, não deixou de ser engajada, consciente e madura.

Dentre as seqüências do Cabra filmado em 64 há imagens que hoje seriam interpretadas como nítidas manifestações de interesse e registro etnográficos. Destacam-se cenas como as da fabricação de farinha de mandioca, de dona Elizabeth e seus filhos cantando um côco e de homens construindo coletivamente uma casa, sugerindo mutirão. Em que medida estas cenas se aproximam de outras seqüências cinemanovistas do Nordeste rural?

Em comparação com Vidas Secas, por exemplo, é possível observar que as imagens de Eduardo Coutinho não denotam seca, nem cangaço. A família de Cabra não é retirante, já que não há deslocamento por causa da 
aridez da terra e de seu proprietário, mas por questões políticas. No filme de Nelson Pereira aparecem formas tradicionais de se fixar o valor do trabalho, contrariamente ao conflito entre patrão e camponeses da Paraíba em torno do aumento do foro. Cabra não apresenta conformismo. Seu camponês é politizado e migra do campo para cidade em sua permanente luta contra o latifúndio, contrariamente ao sertanejo de Vidas Secas que, faminto, se submete aos maus tratos do patrão.

Em análise comparativa entre os trabalhos de Nelson Pereira e Eduardo Coutinho, Iná Elias de Castro (1996) indica que para estes dois diretores o campo não era estereotipado, mas visto como uma solução real de desenvolvimento. Enquadradas em uma leitura de cinema politizado, as propostas de ambos os cineastas contrastam com "nordesterns" de Mazzaropi, por exemplo, pois retratam a figura do camponês enquanto um antijeca, um revolucionário. Segundo Castro, sob esta perspectiva, a compreensão do meio rural brasileiro saía da posição de adorno romântico da nacionalidade para uma dupla e contrastiva representação: por um lado, a luta e o purismo e por outro, um entrave à modernização. Dessa forma, fazia-se necessário distinguir entre o rural camponês, aliado "natural" do proletariado e da revolução, e o rural latifundiário, aliado ao imperialismo. Assim, com uma entrada definitiva no cenário brasileiro, o Nordeste passa a se impor tanto como denúncia de um atraso que busca alguma solução, quanto como uma "brasilidade" pura e revolucionária perdida nos centros urbanos.

A distância entre cidade e interior mostra-se explícita na imagem que abre o filme de Nelson Pereira: a da aproximação de quatro figuras humanas e um cachorro caminhando numa paisagem inóspita. Tal seqüência, segundo Stam e Johnson (1995), sugere um estranhamento cultural entre os personagens camponeses e os espectadores de classe média urbana, fazendo com que a experiência da audiência seja tão "seca" quanto a dos protagonistas. Assim, ao contrário da imagem "sub-representada do camponês no cinema, uma vez que é freqüentemente sentimentalizado de acordo com a ideologia burguesa do filme industrial ocidental, o mérito de Nelson Pereira dos Santos está em evitar essa armadilha, na medida em que não sensacionaliza seu objeto através de confrontos dramáticos, mas mostra eventos cotidianos" (Stam e Johnson 1995:126-27).

As condições marginais e subumanas do Nordeste foram denunciadas algumas vezes através de grandes obras. Vidas Secas, romance de Graciliano Ramos publicado em 1938, se passa no sertão alagoano numa época em que o autoritarismo do Estado Novo eliminara os focos de conflito que acirraram o período revolucionário anterior, em favor da estabilidade e do fortalecimento das instâncias políticas centrais. A reformulação da estrutura agrária, sustentada pelos sólidos e organizados interesses do poder fundiário, fora postergada. Os trabalhadores rurais permaneciam submetidos à exploração condicionada pelas relações de produção vigentes, que acarretavam na completa marginalização de todos os seus processos sociais e políticos. A descrição desta condição que permeia todo o romance confere um aspecto de denúncia social à narrativa. 
Após uma comparação entre o filme homônimo de Nelson Pereira (realizado quase trinta anos depois) e a obra literária, Johnson e Stam indicam que o romance consistia em 129 páginas segmentadas em 13 capítulos, enquanto o filme é composto de 652 cenas articuladas em 69 seqüências com duração de 120 minutos. O romance, publicado originalmente como uma série de trechos autônomos, é readaptado no filme através de uma narrativa coerente e linear. $O$ filme, por exemplo, une os capítulos do romance situados na cidade, 3 e 8 , também escritos de forma menos assustadora. Em seu aspecto histórico, o filme modifica o romance por situar temporalmente a ação descontextualizada pelo escritor. Isso mostra a intenção do cineasta de denunciar a condição do camponês, que seguira sendo oprimido, deixando claro que a situação escrita por Graciliano Ramos décadas antes continuava a existir.

A importância da literatura regionalista para os intelectuais e artistas cinemanovistas fomentou a descoberta de um Brasil que o próprio Brasil desconhecia. No caso de Nelson Pereira, a opção pelo romance de Graciliano Ramos decorrera da vontade de desmistificar a seca como principal causadora da miséria na região, demonstrando que o Nordeste teria mais um problema de relação de trabalho e do regime de propriedade do que de clima simplesmente. Nesse sentido, tanto Cabra Marcado quanto Vidas Secas revelam que a modernidade e a tradição ou a modernização e o conservadorismo brasileiros são agentes que não se excluem entre si e que modelam a tensão do subdesenvolvimento do país.

\section{ESTÉTICA ENGAJADA VERSUS TRAJETÓRIA PESSOAL}

Algumas análises sobre as imagens do Cabra de 64 comparam a ideologia e as práticas do CPC ao método e à estética adotados por Eduardo Coutinho, que não teria necessariamente seguido aquela formação. Walter Lima Júnior, por exemplo, sugere que o "Cabra de 64 estava marcado pelas dominantes de um cinema formalista, politicamente alinhado à estética do popular bem próxima do neo-realismo italiano do pós-guerra e da arte-de-indulgência do CPC da velha UNE" (1984:35). Já Roberto Schwarz (1989) enfatiza suas qualidades em relação ao tratamento das lutas sociais, uma vez que podem ser vistos, na parte do filme realizada em 64, a estupenda dignidade dos camponeses, a singeleza trágica na apresentação dos conflitos de classe e o reconhecimento de tipos não burgueses de beleza. O engajamento cepecista e as características do artista revolucionário são comentados por Miguel Pereira, que sugere que Cabra é o exemplo mais completo de um projeto artístico subordinado a um projeto político. Nesse sentido, "o novo Cabra Marcado mostra com extrema felicidade essa idéia de uma arte popular revolucionária", enquanto o CPC incorpora uma "militância desinteressada, quase uma aventura juvenil" (1985:49), por ter sido mais uma tentativa de revolução cultural do que uma revolução social ou política propriamente dita. 
Essa discussão, importante para percebermos que a memória cinematográfica enquanto um "gênero de discurso" é tão múltipla quanto os diálogos de seus interlocutores, é reinaugurada anos depois em um ciclo de escritos no qual tanto o filme e quanto o diretor são assuntos debatidos nas universidades, através de artigos, livros e teses. Neste âmbito, podemos observar duas principais vertentes: autores que fazem críticas negativas ao filme e ao diretor e autores com atitude de empatia e admiração.

Do primeiro grupo, destacamos o sociólogo Paulo Menezes, que problematiza o conceito de "verdade" imbuído no cinema documentário e seu comprometimento com o "real". Menezes sugere que "a realidade do filme não se identifica nem com a realidade da vida nem a realidade da história, (pois) está na ordem do imaginário, o imaginário sobre o golpe de 64, sobre o 'terror vermelho' e, porque não, o imaginário do próprio Coutinho sobre os camponeses brasileiros" (1995:123). Nesse sentido, o sociólogo afirma que, por se expressar como verdade das coisas, o documentário é o cinema mais mentiroso. Nesse caso, Cabra é apresentado como uma ficção didática na qual seu diretor "demonstra uma grande insegurança em relação às imagens que vai construindo" $\mathrm{e}$ uma necessidade de reafirmar o discurso como verdade que faz com que a montagem ressalte "como as imagens são sempre cuidadosamente e naturalmente naturais" (Menezes 1995:115-118). Segundo Menezes, os recursos técnicos utilizados por Eduardo Coutinho em 64 teriam como objetivo engrandecer os camponeses "filmados sempre com a câmera de baixo para cima, na mais tradicional posição de engrandecimento visual" (1995:123). Assim, a formação política e intelectual do diretor enquanto um cepecista teria buscado denunciar um Estado autoritário contra "pobres" camponeses.

Compartilhando de pensamento similar, Célia Tolentino (1997) sugere que em um primeiro momento a câmera perpassa de baixo para cima, posicionando os camponeses contra o céu, sob o prisma do heroísmo e da força, sempre trabalhando. Ao resgatar o discurso pautado por Bernardet (1967), de que os cinemanovistas eram membros da classe média, intermediária e indecisa entre o operariado e a burguesia, não tendo, portanto, projeto próprio, Tolentino indica que Eduardo Coutinho encarnara o imaginário cinematográfico paternalista dos anos 60, que retratava trabalhadores como minorias desamparadas e subjugadas pela força econômica da propriedade associada aos poderes públicos. Sob aquele ângulo clássico, o camponês aparecia como o "antijeca" para os olhos desenvolvimentistas dos primeiros anos de 60. Para ambos os autores, Cabra estabelece uma fratura histórica entre o "sonho pedagógico-iluminista" de 64 e a realidade nacional encarada vinte anos depois.

Na outra polaridade do debate está a antropóloga Regina Novaes, que desloca a idéia central do filme do âmbito da "verdade". Ao rebater a citação de Menezes de que "todos nós sabemos que a arte não é verdade, a arte é uma mentira que nos permite perceber a verdade; ao menos a verdade que nos é dada a perceber" (1996: 
187), a autora demonstra maior preocupação com o fato de que "as narrativas construídas - em suas dimensões identitárias e simbólicas - devem se transformar em objeto de reflexão sociológica" (1996:188). Nesse sentido, o embate entre realidade e ficção é transposto para o espaço de uma memória coletiva, passando esta a ser vista como uma contextualização histórica que gera questões em permanente redefinição como a própria construção da idéia de campesinato. Para Novaes, o filme seria responsável pelo reconhecimento nacional da figura de um líder importante no processo de organização política dos trabalhadores rurais, e a técnica utilizada pelo diretor teria se empenhado em tornar explícita a complexidade da realidade, numa forma de antropologia reflexiva em que estão presentes diversas conjugações de fatores, entre elas as experiências a posteriori às Ligas Camponesas.

Segundo Novaes, o documentário "fornece um dos elementos fundamentais para a compreensão do contexto histórico no qual se inventou o camponês no Brasil" (1996:191), pois a "aventura" recomeçada por Coutinho vinte anos depois fez com que se redescobrisse o paradeiro de Elizabeth Teixeira, desconhecido até então. Assim, o filme seria responsável, sobretudo, pela retomada da viúva de João Pedro à vida pública, quando teve a oportunidade de transmitir oralmente as conseqüências sofridas pelo regime militar em sua vida pessoal e na luta política. Além disso, a antropóloga chama atenção para o fato de o filme ter nacionalizado a figura de João Pedro Teixeira, que teria encarnado o símbolo do "camponês", naquele momento criado pelo chamado "movimento camponês". Seu assassinato não só consolidaria esta "invenção", dando-lhe sobrevida através da memória social, como tornaria reconhecida nacional e internacionalmente a Liga Camponesa de Sapé. Assim, o filme e seus participantes obtiveram um lugar especial como veículo construtor da memória das Ligas, pois todo o ocorrido antes, durante e depois do golpe é relembrado através de contundentes "testemunhos para a história": a interrupção das filmagens, o que restou do material, os conflitos, as fugas, as torturas, os assassinatos, as desagregações, os reencontros e as reconstituições - fatos que fundamentaram uma memória específica do movimento camponês no Brasil. Nesse sentido, é interessante retomarmos a história do movimento e seu contexto social de forma a clarificar sua relação com a memória construída pelo filme.

\section{O CONTEXTO DO "CABRA" E A FORMAÇÃO DAS LIGAS}

As palavras "camponês" e "campesinato" foram introduzidas pelas esquerdas como forma de "dar conta das lutas dos trabalhadores do campo que irromperam em vários pontos do país nos anos 50" (Martins 1981:21). O significado de "camponês" emana uma concepção histórica de confrontos de classes, de lutas pela despolarização 
da riqueza rural através de uma reforma agrária igualitária e de uma coletivização oposta ao monopólio. Portanto, a definição social de camponês é, sobretudo, política. Segundo Novaes (1997), na memória coletiva agrária há lembranças de camponeses que iam pelos caminhos tentando arregimentar junto aos trabalhadores um grupo cada vez mais coeso para as campanhas e mutirões. Por conseqüência, o ethos camponês se remete à maneira pela qual os trabalhadores articularam e ordenaram experiências sociais coletivamente vividas em um processo concreto de confronto e diferenciação. Assim, a identidade camponesa, delineada a partir da oposição ideológica com o patrão, torna as identidades camponês e latifúndio contrastivas.

Por esse fato, o termo "camponês" fora usado muito restritivamente ao longo do regime militar, sendo substituído por denominações mais "especializadas" como trabalhador rural e rurícola. Por parte dos próprios trabalhadores do campo aquele conceito era reservado para o âmbito da política, já que usualmente eles próprios se autodenominavam como agricultores, lavradores ou apenas trabalhadores. Tais designações permitiam que eles identificassem entre seus próprios pares os companheiros engajados nas Ligas e nos sindicatos daqueles menos envolvidos politicamente. No início, “a designação 'Ligas Camponesas' não era assumida pelas associações de lavradores que no Nordeste se organizaram na segunda metade da década de 50 e início da de 60. Foi usada pela imprensa, e por antagonistas políticos, com o objetivo de estigmatizar tais associações, relacionando-as com o Partido Comunista ilegal, já que a alusão ao comunismo tanto assustava a sociedade ${ }^{10 " ~(N o v a e s ~ 1997: 36) . ~}$

A grande importância da politização do campo fora a mobilização de trabalhadores agrícolas inseridos até então em redes de clientelismo político. Este fato teria provocado efeitos de reestruturação do campo político e o próprio nascimento das Ligas, dando ao camponês a oportunidade efetiva de questionar e lutar contra a ordem social agrária, a legitimidade e a concentração dos poderes dos donos da terra, proporcionando uma mudança nas condições de produção da dominação tradicional.

Engenho da Galiléia. Meados da década de 50, camponeses criam um movimento em resposta às condições em que se encontravam. Assim se constituíram as Ligas Camponesas, primeiro em Pernambuco e depois na Paraíba, precisamente na periferia da região açucareira. Em seu início, o movimento correspondera às primeiras tentativas de utilização das leis existentes, em particular do código civil, para defender na justiça antigos moradores de engenhos abandonados por seus proprietários, e para dar uma assistência jurídica à associação de moradores (Garcia 1988). Nessa época, o Partido Comunista, assim como outras organizações políticas, se mobilizava para uma crescente reorganização do movimento camponês. Desta maneira, as condições do campesinato e a situação de marginalidade do Nordeste em relação a outros estados no processo capitalista 
vieram à tona como forma de denúncia, possibilitando a abertura de um espaço político propício à discussão de questões até então olvidadas, contrariando os interesses das oligarquias tradicionais.

Em 1962, a Associação dos Lavradores e Trabalhadores Agrícolas de Sapé, mais conhecida como Liga Camponesa de Sapé, da qual era líder o "cabra" João Pedro Teixeira, já era a maior do Nordeste, com mais de sete mil sócios. Essa associação obteve uma rápida expansão regional congregando não apenas foreiros do Engenho da Galiléia, mas associados de municípios vizinhos, especialmente porque tinha dois principais objetivos: prestar assistência social e defender direitos de arrendatários, assalariados e pequenos proprietários agrícolas. As Ligas, então, começaram a se expandir, pois se filiaram a elas outros trabalhadores, para além dos "galileus", com novas reivindicações.

Segundo Elide Rugai Bastos (1984), as Ligas foram criadas como único meio legal dos trabalhadores do campo reivindicarem seus direitos, numa época em que a sindicalização rural era uma prerrogativa inexistente. Nesse sentido, abriu-se uma possibilidade de luta contra problemas praticamente desconhecidos para aqueles que viviam nas cidades, tais como: aumento do foro, despejo sem indenização, trabalho obrigatório sem pagamento, violência utilizada pelos latifundiários, entre outros. O movimento ganhou projeção efetiva a partir do momento em que o camponês passou a questionar a representação da propriedade e principalmente quando percebeu a enorme desigualdade existente entre ele e seu patrão - o dono da terra a quem deveria prestar contas e pagar aluguel, o foro.

Um dos fatores mais importantes que fizera com que as Ligas passassem a ser reconhecidas foi a vitória da desapropriação do Engenho da Galiléia, vivida pelos camponeses-atores de Cabra. Seus dirigentes procuravam, primeiramente, conversar diretamente com o proprietário em busca de um entendimento. Caso não houvesse acordo, recorriam ao judiciário. As Ligas da Paraíba, por exemplo, lograram importantes conquistas também em termos de acréscimo da remuneração, como o aumento das diárias em até $15 \%$. Esse valor estabelecido pelo patrão era antes inquestionável, mas a intermediação de líderes possibilitou o estabelecimento de acordos. Em grande parte dos casos, as concórdias trabalhistas eram desrespeitadas mesmo após a promulgação do Estatuto do Trabalhador Rural, de 1963. Para que fossem cumpridas era necessária a pressão feita pelos trabalhadores ou mesmo a criação de eventos políticos, como os "paradeiros" - greves realizadas no próprio local de trabalho.

Vários encontros regionais ocorreram entre 1959 e 1961, como o destacado Congresso de Belo Horizonte, no qual Eduardo Coutinho esteve presente, que constituiu um marco das lutas no campo e pela reforma agrária. Este evento contou com a presença de João Goulart, então presidente da República e reuniu, pela primeira vez, representantes de associações de trabalhadores agrícolas de todo o país e as principais tendências políticas envolvidas na organização: o Partido Comunista Brasileiro, por meio da União dos Lavradores e Trabalhadores 
Agrícolas do Brasil (ULTAB), as Ligas Camponesas, tendo Francisco Julião como sua principal liderança; e o Movimento dos Trabalhadores Sem-Terra (MASTER), do Rio Grande do Sul, liderado por Leonel Brizola (Medeiros 1982). O congresso mobilizou aproximadamente 5.000 pessoas, resultando em um documento onde se discute o direito da organização dos trabalhadores, um maior apoio à economia camponesa, uma melhor distribuição de terras e formas que respondam aos princípios de justiça social.

As lutas que fizeram o camponês emergir de sua exclusão social firmaram-se com o auxílio da intelectualidade de esquerda que, segundo Schwarz, "foi estudando, ensinando, editando, filmando, falando etc, e sem perceber contribuíra para a criação, no interior da pequena burguesia, de uma geração maciçamente anticapitalista" (1978: 63). Ao se expandir por variados campos (sociologia, teologia, historiografia, cinema, teatro, música popular) as problemáticas do movimento camponês e da reforma agrária se inseriram na atmosfera ideológica nacionalista, antiimperialista. Assim, além dos inúmeros tratados acadêmicos sobre os movimentos camponeses e as políticas agrárias no país, artistas e cineastas voltaram sua atenção a essa questão outrora omitida pelas elites. $O$ desejo de instituir uma memória rural brasileira atualizara-se nas telas de cinema.

\section{A HISTÓRIA QUE RESISTE COMO MEMÓRIA}

Segundo Jean-Claude Bernardet, a história ideológica do Cinema Novo seria contada diferentemente se Cabra Marcado para Morrer, o de 64, tivesse sido concluído, uma vez que o filme "se colocaria como um contraponto a relativizar a postura político-ideológica dos filmes do mesmo período" (2003:240). Para Bernardet, contrariamente a Nelson Pereira e aos demais cinemanovistas que se enquadravam numa postura humanista destacando "a miséria de uma massa camponesa sofredora e apática, não só do Nordeste brasileiro, como do campesinato latino-americano e do Terceiro Mundo em geral", Eduardo Coutinho não procurou edificar uma "vaga esperança utópica" (2003:242). Nesse sentido, os camponeses de Coutinho "não são apáticos, mas organizados; formam as Ligas Camponesas e enfrentam concretamente a estrutura agrária e os latifundiários - o que levou ao assassinato de João Pedro" (Bernardet 2003:241).

A partir de fatos atuais é possível verificar que aquele Nordeste apresentado como região emblemática da miséria, do atraso latifundista e do subdesenvolvimento não se encontra, ainda atualmente, em situação dessemelhante. As formas de conservadorismo vigentes demonstram a capacidade de adaptação daquele modelo agrário, que vem se transformando pelos últimos quatro séculos. Considerando o sentido de memória postulado por Halbwachs, que se distingue da história, objetiva e universal, por ser "uma corrente de pensamento 
contínuo, de uma continuidade que nada tem de artificial, já que retém do passado somente aquilo que ainda está vivo ou capaz de viver na consciência do grupo que a mantém" (1990:81), podemos considerar que o contexto histórico das Ligas funda-se numa memória que ainda subsiste enquanto vivência empírica. Assim, o termo "memória histórica", apesar paradoxal, alicerça o Nordeste brasileiro e suas representações, lançando uma ponte entre o passado e o presente, restabelecendo essa continuidade interrompida. Se a criação desta ponte, enquanto denunciação de uma memória injusta e inacabada, for uma das tarefas do cinema, acreditamos que Cabra Marcado concretizou-a de forma bem sucedida. 


\section{NOTAS}

1 Desenvolvido entre dezembro de 1961 e março de 1964, no Rio de Janeiro e em outros estados brasileiros, o CPC foi um movimento idealizado por "jovens artistas, líderes estudantis e pessoas interessadas que possuíam um projeto intelectual comum: a elaboração imperiosa de uma 'cultura popular' em confronto com as expressões artísticas até então vigentes" (Berlinck 1984: 9).

2 Eduardo Coutinho realizou os seguintes documentários: Peões (2004); Edifício Master (2002); Babilônia 2000 (2001); Santo Forte (1999); Os Romeiros do Padre Cícero (1994); Boca de Lixo (1992); O Fio da Memória (1991); Volta Redonda - Memorial da Greve (1989); Santa Marta: Duas Semanas no Morro (1987); Cabra Marcado para Morrer (1964-1984) e Theodorico, Imperador do Sertão (1978).

3 Francisco Julião (1915-1999). Advogado que, a partir de 1955, prestou assistência jurídica à Liga Camponesa da Galiléia. Sua entrada "no movimento dos foreiros marcou um momento decisivo (...). Em sua primeira etapa, o movimento era de autodefesa e tinha um caráter nitidamente legalista. Aos poucos as Ligas, sob a liderança de Julião, passaram a fazer a defesa de uma reforma agrária e a dar, progressivamente, um conteúdo mais orgânico a essa palavra de ordem. Isso se verifica entre 60 e 61, quando o movimento consolida sua expressão nacional e seus ideólogos passam a elaborar mais sua concepção sobre o papel do campesinato nas transformações consideradas necessárias ao país" (Medeiros 1982:51-2).

4 Projeto do CPC da UNE, a UNE-Volante tinha como objetivo visitar as capitais do país de forma a travar contato entre lideranças estudantis, bases universitárias, operárias e camponesas. Nas viagens várias atividades eram desenvolvidas, como a encenação de peças, a exibição de filmes e a apresentação de shows musicais. Para mais detalhes ver Berlinck, op. cit.

5 Trecho de entrevista do diretor concedida à equipe de pesquisa, publicada posteriormente em Cadernos de Antropologia e Imagem, vol. 11, n. 2. UERJ, 2000, sob o título de "A caminho do Nordeste de Cabra Marcado para Morrer: entrevista com Eduardo Coutinho".

6 Diretor de filmes como Maioria Absoluta (1964), A Falecida (1965), São Bernardo (1972), ABC da Greve (1980), Eles Não Usam Blacktie (1981).

7 Filme de 1962, produzido pelo CPC, dividido em cinco episódios: Um Favelado, de Marcos Farias; Zé da Cachorra, de Miguel Borges; Escola de Samba, Alegria de Viver, de Carlos Diegues; Pedreira de São Diogo, de Leon Hiszman; e Couro de Gato (1961), de Joaquim Pedro de Andrade. Este último, realizado em 1960 prévia e independentemente, foi depois incorporado ao projeto Cinco Vezes Favela.

8 Carlos Estevão Martins, um dos fundadores e o mais importante ideólogo do CPC em sua fase inicial, autor da peça $\boldsymbol{A}$ Vez da Recusa (1961), do "Antiprojeto do manifesto do CPC" (1962), e do livro A questão da cultura popular (1963). Oduvaldo Viana Filho, chamado Vianinha, foi autor de A Mais-valia vai Acabar, seu Edgar (1960) e ator principal de Escola de Samba, Alegria de Viver (1962), de Carlos Diegues, episódio de Cinco Vezes Favela. Um dos principais responsáveis pelo setor de teatro do CPC.

9 Entrevista concedida à equipe de pesquisa, op. cit.

10 Segundo Novaes, essa informação Ihe foi dada por Elizabeth Teixeira, quando já teria começado "sua revolta e busca de justiça" (1997: 37). 


\section{REFERÊNCIAS BIBLIOGRÁFICAS}

BASTOS, Elide Rugai. 1984. As Ligas Camponesas. Rio de Janeiro: Vozes.

BERLINCK, Manuel T. 1984. O Centro Popular de Cultura da UNE. Campinas: Papirus.

BERNARDET, Jean-Claude. 2003. Cineastas e imagens do povo. São Paulo: Companhia das Letras. 1967. Brasil em tempo de cinema. Rio de Janeiro: Civilização Brasileira.

CASTRO, Iná E. de. 1996. "Seca versus seca. Novos interesses, novos territórios, novos discursos no Nordeste". Brasil: Questões atuais da reorganização do território. Rio de Janeiro: Bertrand Brasil.

GARCIA JR., Afrânio. 1988. "Libertos e sujeitos, sobre a transição para trabalhadores livres do nordeste”. Revista Brasileira de Ciências Sociais. São Paulo, 3 (7)

HALBWACHS, Maurice. 1990. A memória coletiva. São Paulo: Vértice.

JÚNIOR, Walter Lima. 1984. "Cabra marcado para morrer: a TV como poderia ser". Filme Cultura. Rio de Janeiro, no. 44.

GALANO, Ana Maria et al. 1984. "A cumplicidade com a vida: o real sem aspas. Entrevista com Eduardo Coutinho". Filme Cultura. Rio de Janeiro, no. 44.

LE GOFF, Jacques. 2003. História e memória. Campinas: UNICAMP.

MARTINS, José de Sousa. 1995. Os camponeses e a política no Brasil-as lutas sociais no campo e seu lugar no processo político. Rio de Janeiro: Vozes.

MEDEIROS, Leonilde S. de. 1982. A questão da reforma agrária no Brasil - 1955-1964. Dissertação de Mestrado. São Paulo: USP.

MENEZES, Paulo. 2003. "Representificação: as relações (im)possíveis entre cinema documental e conhecimento". Revista Brasileira de Ciências Sociais 18 (5)

. 1995. "A questão do herói-sujeito em Cabra Marcado para Morrer, filme de Eduardo Coutinho". Tempo Social - Revista de Sociologia da USP. São Paulo no. 6.

NOVAES, Regina R. 1996. “Violência imaginada: João Pedro Teixeira, o camponês no filme de Eduardo Coutinho”. Cadernos de Antropologia e Imagem. Rio de Janeiro, $\mathrm{n}^{\circ} 3$.

1997. De corpo e alma: catolicismo, classes sociais e conflitos no campo. Rio de Janeiro: Graphia.

PEREIRA, Miguel; XAVIER, Ismail e BERNARDET, Jean-Claude. 1985. O desafio do cinema: a política do estado e a política dos autores. Rio de Janeiro: Jorge Zahar Ed.

RICOEUR, Paul. 1998. Histoire et mémoire. De I'histoire au cinéma. Bruxelles: Éditions Complexe. A. de Baecque et C. Delage (dir.)

ROCHA, Glauber. 1981. Revolução do Cinema Novo. Rio de Janeiro: Alhambra/Embrafilme.

SCHWARZ, Roberto. 1978. “Cultura e Política, 1964-1969”. O pai de família e outros estudos. Rio de Janeiro: Paz e Terra. 
. 1989. "O fio da meada". Que horas são? São Paulo: Cia das Letras.

STAM, Robert e JOHSON, Randal. 1995. “The cinema of hunger: Nelson Pereira dos Santos's Vidas Secas". Brazilian Cinema. New York: Columbia University Press.

TOLENTINO, Célia. 1997. A dialética rarefeita entre o não ser e o ser outro - um estudo sobre o rural no cinema brasileiro. Tese de Doutorado. Campinas: Unicamp.

VIANY, Alex. 1962. “Cinema Novo, ano I”. Revista Senhor. Ed. Senhor S.A. Rio de Janeiro, ano 4, nº 5.

XAVIER, Ismail. 1985. O desafio do cinema: a política do estado e a política dos autores. Rio de Janeiro: Jorge Zahar Ed. 


\section{Memórias de um Cabra Marcado pelo cinema: representações de um Brasil rural}

\section{RESUMO}

Com base no documentário Cabra Marcado para Morrer, de Eduardo Coutinho, o artigo analisa as representações do Nordeste rural no cinema brasileiro. Através da história do surgimento das Ligas Camponesas, vemos como o filme trata, a partir da reconstituição biográfica de um líder assassinado da Liga Camponesa de Sapé, as lutas e conseqüências de um movimento camponês. Assim, sob o enfoque da fabricação de significados sociais a partir de signos artísticos, dialogamos com alicerces teóricos sobre o campesinato no Brasil como forma de discutir as representações imagéticas que criam possíveis "espaços históricos".

PALAVRAS-CHAVE: cinema, história, memória, campesinato.

\section{Memories of a "Cabra" Marked by Cinema: representations of a rural Brazil}

\section{ABSTRACT}

Based on Eduardo Coutinho's documentary "Cabra Marcado para Morrer", the article analyzes representation of the northeastern agricultural regions in Brazilian cinema. Through the history of the Ligas Camponesas' sprouting, it is shown how the film portrays, through the biographical reconstitution of an assassinated leader of Liga Camponesa de Sapé, the struggles and consequences of a peasant movement. Thus, by approaching social meanings manufactured by artistic signs, the article dialogues with theoretical foundations of analysis of Brazilian peasantry as a way to discuss the imagetic representations that create possible "historical spaces".

KEY WORDS: cinema, history, memory, peasantry. 